\title{
PENGARUH PERBEDAAN PRE-TREATMENT TERHADAP STABILITAS KAROTENOID DAN FENOL PADA EKSTRAK Sargassum duplicatum SELAMA PENYIMPANAN
}

\author{
Ayunda Dita Wardani, Eko Susanto*, Eko Nurcahya Dewi, Lukita Purnamayati \\ Departemen Teknologi Hasil Perikanan, Fakultas Perikanan dan Ilmu Kelautan, Universitas Diponegoro \\ Jalan Prof Soedarto SH, Tembalang, Semarang, Jawa Tengah - 50275, Telp/Fax +6224 7474698 \\ ${ }^{\star}$ Korespondensi: eko.susanto@live.undip.ac.id \\ Diterima: 22 Mei 2020/Disetujui: 5 Agustus 2020
}

Cara sitasi: Wardani AD, Susanto E, Dewi EN, Purnamayati L. 2020. Pengaruh perbedaan pre-treatment terhadap stabilitas karotenoid dan fenol pada ekstrak Sargassum duplicatum selama penyimpanan. Jurnal Pengolahan Hasil Perikanan Indonesia. 23(2): 236-247.

\begin{abstract}
Abstrak
Karotenoid, fukosantin dan fenol merupakan senyawa yang terkandung pada rumput laut Sargassum duplicatum. Senyawa-senyawa ini berperan dalam menghambat radikal bebas. Namun, kemampuan penghambatan radikal bebas senyawa ini mempunyai kestabilan yang rendah, terutama terhadap perlakuan suhu. Tujuan penelitian ini adalah untuk menentukan pengaruh pre-treatment suhu tinggi (blanching) dan suhu rendah (pembekuan) serta perlakuan terbaik yang dapat mempertahankan stabilitas senyawa aktif pada ekstrak metanol rumput laut selama penyimpanan. Metode penelitian yang digunakan adalah experimental laboratories menggunakan rancangan acak lengkap (RAL) faktorial $2 \times 5$ yaitu pola terbagi menjadi faktor suhu pengolahan (suhu tinggi dan suhu rendah) dan lama penyimpanan $(0,2,4,6$, dan 8 hari). Blanching dilakukan pada suhu $95^{\circ} \mathrm{C}$ sedangkan pembekuan pada suhu $-27^{\circ} \mathrm{C}$. Hasil penelitian menunjukkan karotenoid, fukosantin, dan senyawa fenol dengan perlakuan blanching lebih stabil dibandingkan perlakuan pembekuan. Berdasarkan hasil penelitian menunjukkan bahwa adanya interaksi antara pre-treatments dan lama penyimpanan yang berpengaruh nyata terhadap nilai total karotenoid, kandungan fukosantin, total kandungan fenol, dan nilai perubahan warna $(\Delta \mathrm{E})$.
\end{abstract}

Kata kunci: blanching, fenol, fukosantin, karotenoid

\section{The effect of different pre-treatments on carotenoid and phenol stability of Sargassum duplicatum methanol extract during storage}

\begin{abstract}
Carotenoids and phenols, compounds contained in seaweed, have free radical scavenging activities. However, both compounds have low stability. Temperature, in particular, may affect the stability of both compounds. The aim of this study was to determine the effects of different pre-treatments, namely, blanching (high temperature) and freezing (low temperature), on maintaining the stability of methanol extracts of Sargassum duplicatum during storage at room temperature. The research method used was an experimental laboratory study using the basic design of a completely randomized design with a factorial pattern of $2 \times 5$, which was divided into the factors of processing temperature (high and low temperature) and storage time $\left(0,2,4,6\right.$, and 8 days). Blanching was carried out at a temperature of $95^{\circ} \mathrm{C}$, whereas freezing was carried out at $-27^{\circ} \mathrm{C}$. The results showed that carotenoids, fucoxantin, and phenol compounds were more stable in the blanching treatment than in the freezing treatment. This study showed that blanching effectively delayed the degradation of carotenoids, fucoxanthin, and phenol content during storage at room temperature.
\end{abstract}

Keywords: blanching, carotenoids, fucoxanthin, phenol

\section{PENDAHULUAN}

Sargassum merupakan salah satu genus rumput laut cokelat yang mempunyai potensi produksi sebesar 482.400 ton/tahun (Basmal 2009). Potensi Sargassum berkaitan dengan kandungan senyawa bioaktif antara lain karotenoid dan polifenol (Milledge et al. 2016). Karotenoid merupakan senyawa isoprenoid yang larut dalam lemak dan memberikan warna kuning, merah dan jingga pada buah, bunga, burung, dan udang (Fraser and Bramley 2004; Yilmaz et al. 2015). Karotenoid bersama dengan klorofil berkontribusi memberikan warna cokelat atau hijau zaitun pada Phaeophyta (Hosokawa et al. 2009). Jenis karotenoid yang dominan terdapat 
dalam Sargassum sp. adalah fukosantin (Fs) (Susanto et al. 2016, Susanto et al. 2019). Sedangkan senyawa fenol merupakan metabolit sekunder berbentuk cincin benzen aromatik yang memiliki satu atau lebih gugus hidroksil yang terikat langsung dengan cincin aromatik, termasuk turunan fungsionalnya. Pada rumput laut, senyawa ini mempunyai struktur yang sederhana seperti asam fenolat hingga yang paling komplek yaitu florotanin (Mekini'c et al. 2019).

Salah satu metode untuk mengekstrak senyawa bioaktif pada rumput laut adalah dengan menggunakan pelarut metanol. Beberapa penelitian yang menggunakan pelarut metanol untuk esktraksi di antaranya ekstraksi rumput laut Padina dan E. cottonii (Maharany et al. 2017), E. cottonii dan Sargassum plagyophlum (Dolorosa et. al 2019; Dolorosa et al. 2017), E. cottonii dan Turbinaria sp. (Yanuarti et al. 2017), E. cottonii dan Sargassum sp. (Hidayat et al. 2018; Luthfiyana et al. 2016; Nurjanah et al. 2017), dan Caulerpa (Nurjanah et al. 2016). Ekstrak metanol pada rumput laut cokelat mempunyai aktivitas antioksidan yang tinggi dan berpotensi dapat diaplikasikan pada pangan dan industri farmasi (Sullivan et al. 2011). Ekstrak metanol rumput laut cokelat mengandung beberapa senyawa antara lain karotenoid (Aranthi et al. 2011, Zaragoza et al. 2008), fenol (Airanthi et al. 2009, Sullivan et al. 2011; Jaswir et al. 2014), klorofil (Rattaya et al. 2014), dan lain-lain. Karotenoid dan fenol mempunyai aktivitas sebagai antioksidan yang tinggi (Fiedor dan Burda 2014; Vinson et al. 2001) namun memiliki tingkat kestabilan yang rendah. Faktor cahaya, suhu, oksidator, reduktor, $\mathrm{pH}$, dan peran enzim dalam proses degradasi (Kerasely and Rodriguez 1981; Ali et al. 2018) berpengaruh terhadap tingkat kestabilan kedua senyawa tersebut.

Studi tentang kestabilan karotenoid dan fenol yang diekstrak dari rumput laut telah dilakukan oleh beberapa penelitian sebelumnya. Yip et al. (2014) menguji stabilitas fukosantin yang diekstrak dari S. binderi terhadap beberapa parameter seperti $\mathrm{pH}$, cahaya, dan suhu. Stabilitas pigmen dari S. duplicatum terhadap penambahan oksidator dan reduktor juga telah dilakukan (Rahmawaty et al. 2014). Florotanin, senyawa fenol pada rumput laut cokelat, yang diisolasi dari Fucus vesiculosus diuji stabilitasnya pada berbagai suhu penyimpanan (Kirke et al. 2017). Selain faktor-faktor tersebut, perbedaan metode pengolahan/ pre-treatment juga memengaruhi kestabilan pigmen dan total fenol (Susanto et al. 2017). Namun sedikit sekali penelitian yang dilakukan untuk efek perbedaan pre-treatment terhadap stabilitas senyawa yang terkandung pada ekstrak rumput laut.

Oleh karena itu, penelitian ini bertujuan mengetahui pengaruh perbedaan pretreatment terhadap kandungan karotenoid, pigmen, dan fenol pada ekstrak metanol S. duplicatum dan pre-tretment terbaik yang memengaruhi kestabilan kedua senyawa tersebut selama penyimpanan pada suhu ruang.

\section{BAHAN DAN METODE Bahan dan Alat}

Bahan yang digunakan dalam penelitian ini yaitu S. duplicatum yang diambil dari perairan Bandengan Jepara. Bahan kimia yang digunakan untuk penelitian ini adalah metanol teknis, acetonitril pro analysis (Merck), methanol pro analysis (Merck), asam galat (Sigma-Aldrich), Folin Ciocalteu 2N (Sigma-Aldrich), dan sodium karbonat (Sigma-Aldrich).

Peralatan yang digunakan untuk pengujian antara lain waterbath (Wisebath), freezer, rotary vacum evaporator (Buchi R-210), timbangan analitik (Durascale), sonikator (Shimadzu), spektrofotometer UV-Vis (Shimadzu), High Performance Liquid Chromatography (HPLC) LC20AD UV detector (Shimadzu), Digital Color Meter GM52223LSG (Apple).

\section{Pre-treatment dan ekstraksi S. duplicatum}

S. duplicatum dicuci menggunakan air tawar untuk menghilangkan semua kotoran dan epifit yang menempel. Selanjutnya diberi dua perlakuan yang berbeda yaitu direndam dengan teknik hot water blanching $\left(90^{\circ} \mathrm{C}\right.$ selama 90 detik) (Liu et al. 2011) dan penyimpanan 


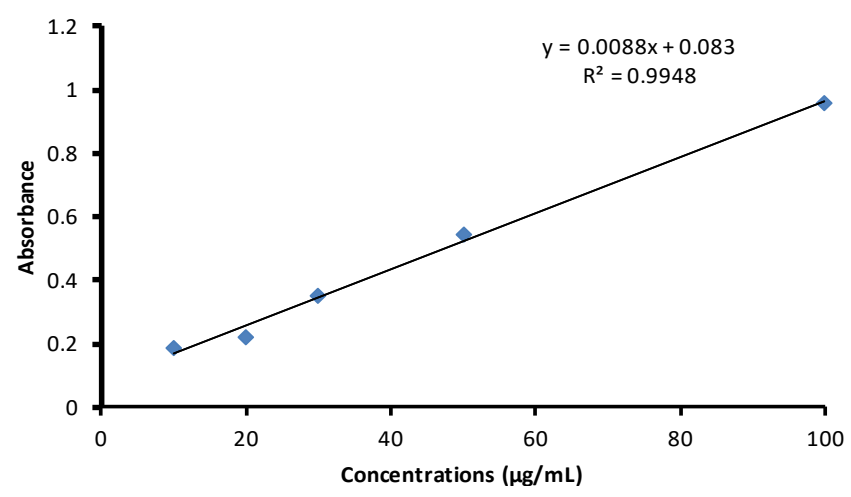

Figure 1 Phenolic content standard prepared from gallic acids.

di refrigerator $\left(-27^{\circ} \mathrm{C}\right.$ selama 7 hari). Setelah dilakukan perlakuan pre-treatment dilakukan ekstraksi berdasarkan Hii et al. (2010), dengan merendam S. duplicatum pada pelarut metanol selama satu malam. Selanjutnya, dipisahkan antara pelarut dan ekstrak dengan rotary evaporator suhu $\left(35-40^{\circ} \mathrm{C}\right)$ sehingga diperoleh ekstrak metanol S. duplicatum.

\section{Penyimpanan ekstrak $S$. duplicatum}

Konsentrat ekstrak metanol S. duplicatum dilarutkan kembali ke dalam metanol dengan konsentrasi $2 \mathrm{mg} / \mathrm{ml}$ untuk setiap botol vial $(30 \mathrm{~mL})$ dan dihomogenisasi dengan sonikator kemudian dialiri gas $\mathrm{N}_{2}$ untuk menghilangkan $\mathrm{O}_{2}$ yang dapat berperan sebagai oksidator selama proses penyimpanan. Selanjutnya, ekstrak disimpan pada suhu ruang dan terpapar sinar matahari $\left(33-37^{\circ} \mathrm{C}\right)$ selama delapan hari. Setiap dua hari ekstrak metanol S. duplicatum diuji kandungan karotenoid dan fukosantin, uji total kandungan fenol, dan uji total perubahan warna $(\Delta \mathrm{E})$.

\section{Uji total karotenoid}

Metode yang digunakan dalam pengujian total karotenoid berdasarkan Lichtenthaler dan Buschmann (2001). Spektrofotometer UV-Vis diatur untuk menguji sampel pada tiga panjang gelombang yang berbeda yaitu 665,652 , dan $470 \mathrm{~nm}$. Angka absorbansi ditampilkan pada layar. Angka yang telah didapatkan dimasukkan ke dalam rumus kandungan total karotenoid dengan pelarut Metanol (pure solvent), yaitu:

$$
\begin{aligned}
& \mathrm{ca}(\mu \mathrm{g} / \mathrm{mL})=16,72 \mathrm{~A}_{665}-9,16 \mathrm{~A}_{652} \\
& \mathrm{cb}(\mu \mathrm{g} / \mathrm{mL})=34,09 \mathrm{~A}_{665}-15,28 \mathrm{~A}_{652 \mathrm{i}} \\
& \mathrm{c}(\mathrm{x}+\mathrm{c})(\mu \mathrm{g} / \mathrm{mL})=\frac{\left(1000 \mathrm{~A}_{470}-1,63 \mathrm{ca}-95,15 \mathrm{cb}\right)}{225}
\end{aligned}
$$

\section{Analisis kandungan fukosantin}

Pengujian fukosantin (Fs) pada ekstrak rumput laut dilakukan berdasarkan Susanto $e t$ al. (2016). Sekitar $20 \mu \mathrm{L}$ sampel ekstrak rumput laut yang dilarutkan dalam metanol digunakan untuk menganalisis fukosantin. Sebelum injeksi, ekstrak sampel disaring melalui bulk Acrodisc PSF Syringe Filter 0,45 pM GHP membrane, $25 \mathrm{~mm}$. Analisis dilakukan dengan menggunakan fase gerak gradien biner yang terdiri dari metanol (A)/acetonitril (B) (7:3). Laju aliran adalah $1 \mathrm{~mL} /$ menit dari 0 sampai 30 menit. Deteksi kromatografi Fs dilakukan pada panjang gelombang $450 \mathrm{~nm}$.

\section{Uji kandungan total fenol}

Pengujian kandungan total fenol (TF) dilakukan berdasarkan Kuda et al. 2005. Sebanyak $100 \mu \mathrm{L}$ larutan sampel ke $750 \mu \mathrm{L} 10 \%$ larutan Folin-Ciocalteu kemudian diinkubasi pada suhu $37^{\circ} \mathrm{C}$. Setelah lima menit, $750 \mu \mathrm{L} 6 \%$ $\mathrm{Na}_{2} \mathrm{CO}_{3}$ ditambahkan dan campuran dibiarkan pada suhu $37^{\circ} \mathrm{C}$ selama 30 menit dalam gelap. Absorbansi diukur pada $750 \mathrm{~nm}$. TPC untuk setiap ekstrak rumput laut kemudian dihitung atas dasar kurva standar asam galat dan dinyatakan sebagai mg asam galat (GA)/g ekstrak. Total fenol dalam $\mu \mathrm{g}$ GAE/g didapatkan dengan mengalibrasikan hasil pengukuran dengan persamaan kurva standar asam galat $\mathrm{y}=0,0088 \mathrm{x}+0,083$ dan $\mathrm{R} 2=0,9948$ (Figure 1). Total fenol dalam bahan dihitung dengan rumus:

Total Fenol $(\mathrm{mg} \mathrm{GAE} / \mathrm{g})=\frac{\text { C GAE x volume }(\mathrm{mL})}{\text { Massa bahan }(\mathrm{g})}$

\section{Nilai total perubahan warna $(\Delta \mathrm{E})$}

Warna ekstrak dapat ditentukan dengan mengukur nilai $L, a^{*}$, and $b^{*}$. Prosedur kerja 
pengujian warna yaitu ekstrak ditempatkan di dalam wadah berbentuk cekung berwarna putih dan diletakkan di bawah kamera digital dan cahaya lampu berwarna putih. Pada perangkat lunak Digital Color Meter akan terlihat warna yang terekam oleh kamera kemudian kursor diarahkan pada bagian dalam gambar yang menunjukkan keberadaan ekstrak. Nilai L, $\mathrm{a}^{*}$, dan $\mathrm{b}^{*}$ akan terlihat pada layar komputer. Perhitungan nilai total perubahan warna $(\Delta \mathrm{E})$ menggunakan rumus berikut:

$\Delta \mathrm{E}=\left((\Delta \mathrm{L})^{2}+(\Delta \mathrm{a})^{2}+(\Delta \mathrm{b})^{2}\right)^{1 / 2}$

\section{Analisis data}

Rancangan percobaan yang digunakan yaitu rancangan acak lengkap (RAL) faktorial dengan dua suhu dan lima waktu penyimpanan. Data diolah menggunakan SPSS 21. Data hasil pengujian selanjutnya diuji statistik dengan uji normalitas, uji homogenitas, uji ANOVA, dan uji lanjut (BNJ).

\section{HASIL DAN PEMBAHASAN Perubahan Karotenoid Penyimpanan}

Karotenoid merupakan pigmen yang larut dalam lemak sehingga senyawa ini dapat terekstrak dalam pelarut organik metanol (Park et al. 2007). Rumput laut cokelat mengandung beberapa jenis karotenoid antara lain zeaksantin (Zs), violasantin (vs), beta-karoten ( $\beta$-kar), dan Fs (Susanto et al. 2019). Karotenoid pada ekstrak metanol S. duplicatum mengalami degradasi selama penyimpanan suhu ruang yang terpapar sinar matahari (Figure 2).

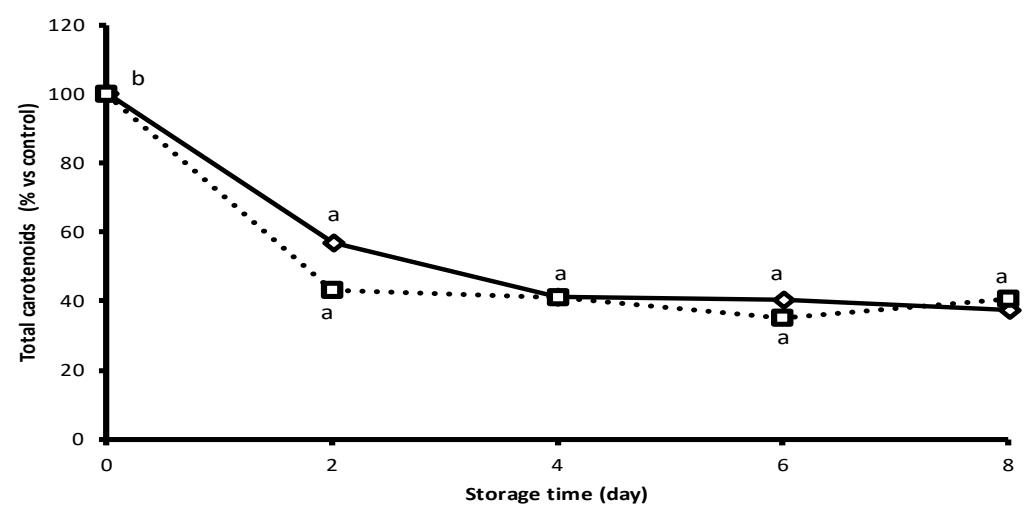

Ekstrak metanol S. duplicatum selama penyimpanan pada suhu ruang mengalami penurunan yang signifikan pada awal penyimpanan (hari ke-0-2), selanjutnya cenderung stabil hingga akhir penyimpanan pada kedua perlakuan. Hasil kandungan total karotenoid pada hari kedua perlakuan blanching lebih besar satu setengah kali lipat dibandingkan dengan perlakuan beku. Pada akhir penyimpanan (hari ke-8) terjadi penurunan karotenoid sebesar 53,14\% (blanching) dan 70,97\% (beku). Hasil tersebut menunjukkan bahwa blanching memberikan kestabilan lebih baik terhadap kandungan total karotenoid pada ekstrak metanol $S$. duplicatum dibandingkan pembekuan. Blanching diketahui mampu mempertahankan kandungan karotenoid pada goseberi (Ahn dan Coe 2015), wortel (Behesniliian dan Mayer-Mieback 2017), akar seledri (Priecina et al. 2018) dibandingkan tanpa treatment blanching. Selain itu, blanching mampu mempertahankan kandungan karotenoid pada wortel kintoki dibandingkan dengan penyimpanan beku (Mayer dan Spiess 2003).

Hal ini dikarenakan perlakuan blanching mampu menghambat aktivitas enzim sehingga memperlambat proses oksidasi dan degradasi karotenoid. Aktivitas enzim atau sistem enzim dapat dirusak pada suhu $\pm 200^{\circ} \mathrm{F}$ $\left(93,3^{\circ} \mathrm{C}\right)$. Enzim masih memiliki sebagian aktivitasnya pada suhu $-100^{\circ} \mathrm{F} \quad\left(-37,8^{\circ} \mathrm{C}\right)$ walaupun kecepatan reaksinya sangat rendah pada suhu tersebut (Rohanah 2002). Enzim lipoxigenase yang berperan dalam degradasi

\footnotetext{
temperature $\left(33-37^{\circ} \mathrm{C}\right)$ exposed to sunlight; results are expressed as mean $\pm S D$ of triplicates samples; $\diamond$ blanching $\square$ frozen; Different superscript on the same row indicated significant difference $(p<0.05)$ vs control (day 0$)$.
}

Figure 2 Total carotenoids changes of Sargassum duplicatum methanol extract during storage at room 
pigmen golongan karotenoid (Biac dan Daood 2001; Gayen et al. 2015) dapat diminimalisasi/ diinaktivasi dengan proses blanching (Garrotte et al. 2004).

Penurunan jumlah kandungan karotenoid menandakan adanya proses degradasi menjadi beberapa produk degradasinya selama penyimpanan pada suhu ruang dan adanya paparan cahaya sinar matahari. Pengaruh suhu dan paparan sinar matahari mempercepat proses degradasi karotenoid selama penyimpanan (Gouveia dan Empis, 2003) seperti $\beta$-kar (Liu et al. 2009), Fs (Zhao et al. 2018), dan Zs (Xiao et al. 2018).

Penyimpanan suhu ruang yang berkisar antara $\left(33-37^{\circ} \mathrm{C}\right)$ berperan dalam mempercepat proses degradasi menjadi senyawa turunannya. Stabilitas karotenoid tersebut berkaitan dengan keberadaan ikatan rangkap dalam struktur molekul karotenoid, menyebabkan terjadinya perubahan struktur dengan mudah. Degradasi karotenoid akan menyebabkan terbentuknya senyawa turunan cis karena proses isomerasi yang dipicu oleh cahaya, suhu, asam, enzim, dan sebagainya (Heriyanto dan Limantara 2010).

\section{Perubahan Fs selama Penyimpanan}

Fukosantin merupakan karotenoid yang paling dominan di rumput laut cokelat termasuk jenis Sargassum (Nomura et al. 2013; Susanto et al. 2016; Susanto et al. 2019). Selama penyimpanan pada suhu ruang, Fs pada ekstrak metanol S. duplicatum mengalami degradasi (Figure 3).
Pada awal penyimpanan (hari ke0 ) penyimpanan, kandungan Fs berbeda pada setiap perlakuan. Kandungan Fs pada perlakuan blanching sebanyak $73,7 \mathrm{mg} / \mathrm{L}$ sedangkan pada perlakuan beku sebanyak 110,6 mg/L. Adanya perbedaan jumlah kandungan Fs terhadap kedua perlakuan pada hari ke-0 karena pada perlakuan blanching menggunakan suhu tinggi yang dapat menyebabkan adanya degradasi Fs. Pada penyimpanan hari ke-0 hingga hari ke-2 terjadi penurunan Fs yang signifikan pada kedua perlakuan. Hingga akhir penyimpanan kandungan $F$ s mengalami penurunan hingga $80,44 \%$ (blanching) dan 87,51\% (pembekuan) (Figure 2). Hasil tersebut diperkuat dengan hasil kromatogram (Figure 4) antar kedua perlakuan. Jumlah penurunan Fs berkolerasi dengan penurunan jumlah total karotenoid (Figure 2) dalam ekstrak metanol S. duplicatum. Hal ini dikarenakan Fs merupakan karotenoid yang dominan pada Sargassum sp. (Terasaki et al. 2009; Nomura et al. 2013; Yip et al. 2014; Susanto et al. 2016; Susanto et al. 2019). Selama penyimpanan pada suhu ruang terjadi proses isomerisasi (trans ke cis) Fs. Proses degradasi akan menghasilkan turunan senyawa fukosantin yaitu 9'-cis Fs, 13 cis Fs, dan 13'-cis Fs (Heo et al. 2008). Proses perubahan tersebut disebabkan oleh suhu yang tinggi baik pada saat ekstraksi dan saat penyimpanan (Hii et al. 2010; Bonn et al. 2010; Kawee-ai et al. 2013; Susanto et al. 2017; Zhao et al. 2019) maupun pengaruh cahaya

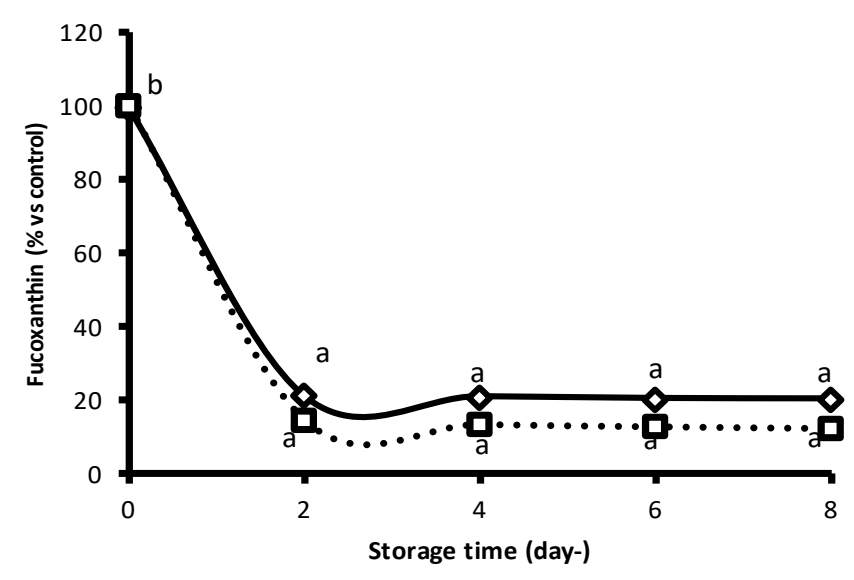

Figure 3 Fucoxanthin content changes of Sargassum duplicatum methanol extract during storage at room temperature $\left(33-37^{\circ} \mathrm{C}\right)$ exposed to sunlight; results are expressed as mean $\pm \mathrm{SD}$ of triplicates samples; different superscript on the same row indicated significant difference $(p<0.05)$ vs day 0. 

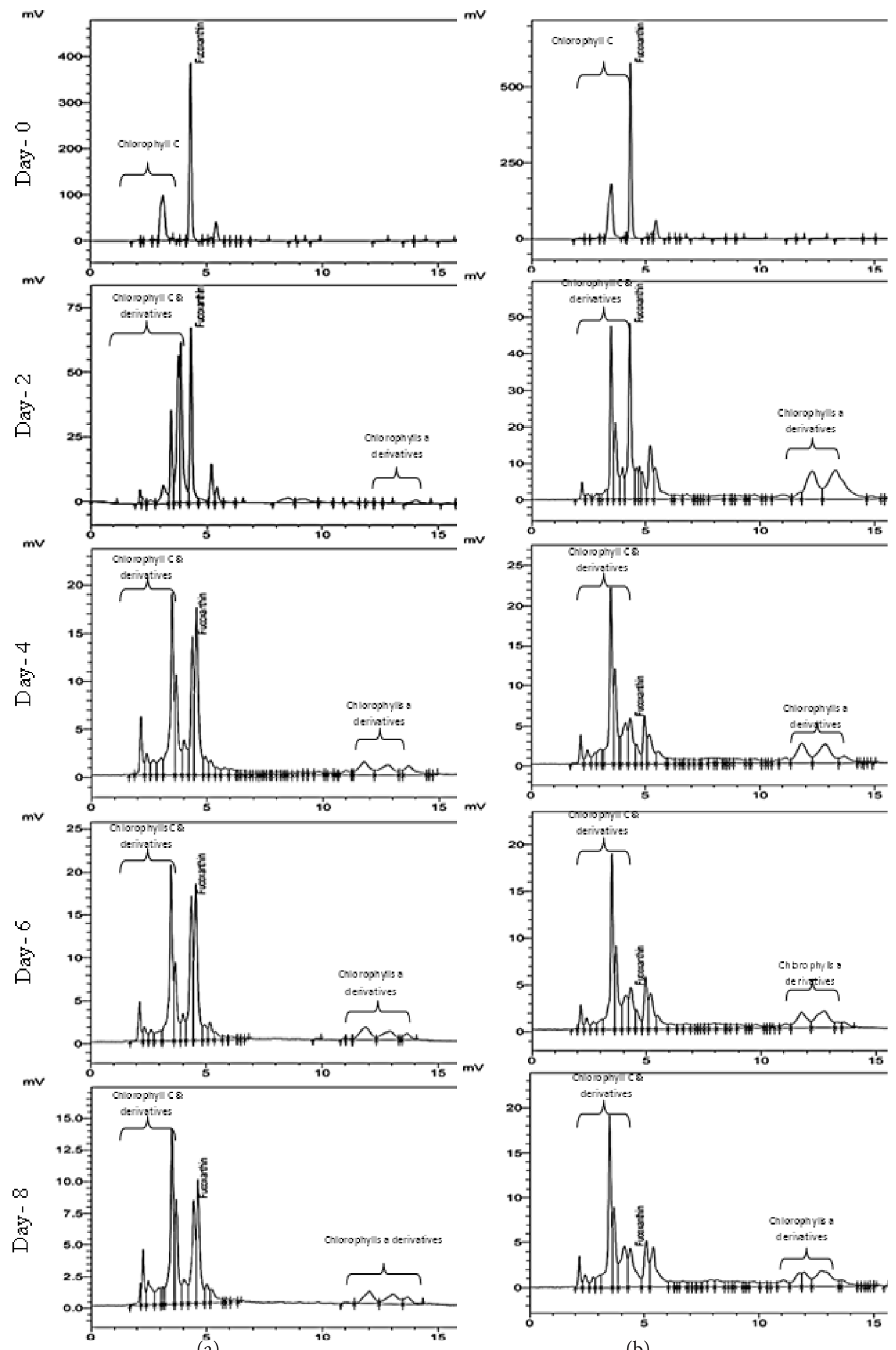

(a)

(b)

Figure 4 Representative chromatogram of pre-treatment of Sargassum duplicatum metanol extract during storage at room temperature $\left(33-37^{\circ} \mathrm{C}\right)$ exposed to sunlight; (a) blanching; (b) freezing 


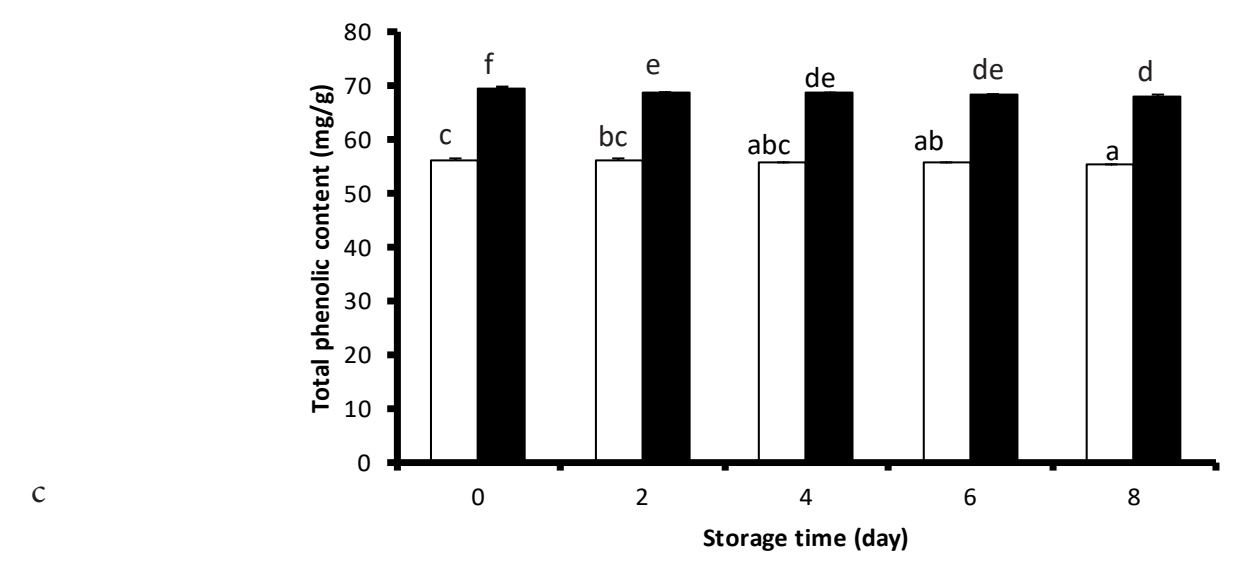

Figure 5 Changes of total phenolic content of Sargassum duplicatum methanol extract during storage at room temperature $\left(33-37^{\circ} \mathrm{C}\right)$ exposed to sunlight; results are expressed as mean $\pm S D$ of triplicates samples; $\square$ blanching; $\square$ frozen.

(Yip et al. 2014). Salah satu penyebab ketidakstabilan Fs selama penyimpanan adalah adanya ikatan allenik yang menyebabkan stabilitasnya rendah (Zhang et al. 2015)

\section{Kandungan Total Fenol}

Ekstrak metanol pada rumput laut cokelat Sargassum mengandung senyawa fenol (Magnusson et al. 2017; Puspita et al. 2017) antara lain eckol, asam galat, florotanin, katekin, epikatekin, quercetin, dan phlorotannin (Mekini' et al. 2019). Untuk mengetahui perubahan total fenol (TF) pada ekstrak metanol S. duplicatum maka pada penelitian ini melihat perubahan TF pada kedua pretreatment (Figure 5).

Kandungan TF pada perlakuan blanching lebih rendah dibandingkan dengan perlakuan beku. Hal ini sesuai dengan penelitian Cox et al. (2011) dan Susanto et al. (2017) bahwa blanching menurunkan kandungan TF pada rumput laut.

Selama penyimpanan kandungan $\mathrm{TF}$ lebih stabil dibandingkan karotenoid maupun fukosantin. Hingga akhir penyimpanan (hari ke-8), kandungan fenol turun sebesar 1,24\% (perlakuan blanching) dan 2,23\% (perlakuan beku). Proses degradasi senyawa fenol berjalan lambat pada penelitian ini. Hal ini dikarenakan TF lebih stabil dibandingkan dengan karotenoid (Donado-Pestana et al. 2012).

Penurunan kandungan TF pada perlakuan beku lebih banyak dibandingkan dengan perlakuan pengolahan blanching. Berdasarkan hasil tersebut, terlihat bahwa blanching mampu mempertahankan senyawa fenol dibandingkan dibandingkan pembekuan.

\section{Total Perubahan Warna $(\Delta E)$}

Total perubahan warna menunjukkan terjadinya perubahan warna secara keseluruhan pada sampel selama penyimpanan. Total perubahan warna yang terjadi cukup signifikan. Hasil total perubahan warna perlakuan blanching hingga hari ke-8 sebesar 39,60 dengan nilai $L^{*}$ 69,47 sedangkan pada perlakuan beku total perubahan sebesar 57,00 dengan nilai $L^{*} 81,77$. Perubahan warna berkaitan dengan penurunan kandungan pigmen pada ekstrak metanol S. duplicatum yang diakibatkan oleh perubahan struktur pada karotenoid dan derifat klorofil (Figure 4). Ekstrak metanol S. duplicatum tidak hanya mengandung karotenoid tetapi juga mengandung klorofil dan derivatnya. Nilai total perubahan warna $(\Delta \mathrm{E})$ yang diperoleh dapat dilihat pada Table 1.

Nilai total perubahan warna lebih besar pada pre-treatment blanching dibandingkan dengan pre-treatment beku. Penyimpanan yang dilakukan di ruang terbuka memungkinkan kontak langsung dengan cahaya sehingga menyebabkan reaksi fotooksidasi yang berakibat terdegradasinya senyawa karotenoid maupun klorofil. Isomer cis tetap mempertahankan sifat warna dari karotenoid asalnya, sedangkan produk degradasi tidak 
Table 1 Changes of lightness and color of $S$. duplicatum metanol extract during storage at room temperature

\begin{tabular}{cccc}
\hline Treatment & Storage time (days) & Lightness $\left(\mathrm{L}^{*}\right)$ & Color changes $(\Delta \mathrm{E})$ \\
\hline \multirow{3}{*}{ Blanching } & 0 & $45.49 \pm 3.65$ & $0 \pm 0^{\mathrm{a}}$ \\
& 2 & $51.03 \pm 2.96$ & $12.47 \pm 2.09^{\mathrm{b}}$ \\
& 6 & $53.63 \pm 0.88$ & $30.94 \pm 4.06^{\mathrm{c}}$ \\
& 8 & $63.63 \pm 2.15$ & $37.39 \pm 2.57^{\mathrm{d}}$ \\
\multirow{3}{*}{ Freezing } & 0 & $69.47 \pm 0.75$ & $39.60 \pm 1.21^{\mathrm{d}}$ \\
& 2 & $62.04 \pm 1.48$ & $0 \pm 0^{\mathrm{a}}$ \\
& 4 & $71.66 \pm 0.52$ & $12.29 \pm 1.14^{\mathrm{b}}$ \\
& 6 & $72.58 \pm 1.19$ & $37.31 \pm 2.08^{\mathrm{d}}$ \\
& 8 & $77.69 \pm 1.49$ & $46.65 \pm 1.03^{\mathrm{e}}$ \\
\hline
\end{tabular}

Note: Results are expressed as the mean \pm SD of triplicates samples; different superscript letters in a row show the significant differences $(p<0.05)$

berwarna karena menghasilkan kromofor yang lebih pendek (Heriyanto dan Limantara 2010). Sedangkan klorofil akan berubah menjadi produk derivatnya yang berwarna abu-abu.

Hal ini juga terjadi pada penelitian Hii et al. (2004), semua sampel yang disimpan dalam kondisi gelap menunjukkan nilai chroma tinggi dan peningkatan nilai kecerahan yang rendah jika dibandingkan dengan sampel yang terkena cahaya, menunjukkan stabilitas karotenoid yang lebih baik akan terjadi dengan ketidakhadiran dari sumber cahaya.

Kenaikan total perubahan warna berhubungan dengan penurunan kadar karotenoid dan fukosantin serta naiknya kandungan derivat klorofil. Semakin turun kandungan pigmen maka akan semakin tinggi nilai total perubahan warna. Warna ekstrak metanol S.duplicatum dengan pengolahan blanching berubah dari warna hijau kuning pekat menjadi kuning bening pada hari ke8. Pada pengolahan beku perubahan lebih jelas terlihat dari hijau kuning sangat pekat menjadi kuning bening pada hari ke-8. Hii et al. (2010) melaporkan bahwa semakin besar nilai $L$ maka mengindikasikan warna sampel semakin terang. Pendapat lain disebutkan oleh Kartikaningsih dan Zaelani (2014), bahwa degradasi pigmen juga bisa dilihat dari pemucatan warna yang diduga disebabkan oleh pemutusan ikatan rangkap.

\section{KESIMPULAN}

Perbedaan pre-treatment pada S. duplicatum sebelum diekstrak berpengaruh terhadap kestabilan karotenoid, Fs, dan fenol pada metanol ekstrak $S$. duplicatum selama penyimpanan suhu ruang. Nilai kandungan karotenoid, Fs, dan fenol menurun selama penyimpanan, sedangkan nilai kecerahan dan total nilai perubahan warna pada sampel meningkat. Pre-treatment blanching mampu mempertahankan stabilitas karotenoid dan Fs rumput laut pada ekstrak S.duplicatum selama penyimpanan pada suhu ruang.

\section{UCAPAN TERIMA KASIH}

Penulis mengucapkan terima kasih kepada Universitas Diponegoro yang telah membiayai sebagian dari penelitian ini dengan skim Riset Penerapan dan Pengembangan tahun 2016.

\section{DAFTAR PUSTAKA}

Ahn H, Cheo E. 2015. Effects of blanching and drying on pigments and antioxidants of daraesoon (shoot of the Siberian gooseberry tree, Actinidia arguta Planchon). Food Science and Biotechnology. 24:1265-1270.

Airanthi MKWA, Hosokawa M, Miyashita K. 2011. Comparative antioxidant activity of edible Japanese brown seaweeds. Journal of Food Science. 76 (1): C104-111 
Ali A, Chong $\mathrm{CH}$, Mah SH, Abdullah LC, Shean T, Choong Y, Chua BL. 2018. Impact of storage conditions on the stability of predominant phenolic constituents and antioxidant activity of dried Piper betle extracts. Molecules. 23(2):484

Basmal J. 2009. Prospek pemanfaatan rumput laut sebagai bahan pupuk organik. Squalen. 4(1):1-7.

Behsnilian D, Mayer-Miebach E. 2017. Impact of blanching, freezing and frozen storage on the carotenoid profile of carrot slices (Daucus carota L. cv. Nutri Red). Food Control. 73 (B):761-767.

Boon CS, Mcclements J, Weiss J, Decker EA. (2010) Factors influencing the chemical stability of carotenoids in foods. Critical Reviews in Food Science and Nutrition. 50(6): 515-532.

Cox S, Gupta S, Abu-Ghannam N. 2011. Application of response surface methodology to study the influence of hydrothermal processing on phytochemical constituents of the Irish edible brown seaweed Himanthalia elongata. Botanica Marina. 54(5):471480.

Dolorosa MT, Nurjanah, Purwaningsih, Anwar E, Hidayat T.2019. Tyrosinase inhibitory activity of Sargassum plagyophyllum and Eucheuma cottonii methanol extracts. IOP Conf. Ser.: Earth Environ. Sci. 278012020

Dolorosa MT, Nurjanah, Purwaningsih, Anwar E, Hidayat T. 2017. Kandungan senyawa bioaktif bubur rumput laut Sargassum plagyophyllum dan Eucheuma cottonii sebagai bahan baku krim pencerah kulit. Jurnal Pengolahan Hasil Perikanan Indonesia. 20(3): 633-644.

Donado-Pestana C M, Salgado, J M, de Oliveira Rios, A. dos Santos P R, Jablonski A. 2012. Stability of carotenoids, total penolics and in vitro antioxidant capacity in the thermal processing of orange fleshed sweet potato (Ipomoea batatas Lam.) cultivars grown in Brazil. Plant Foods Human Nutrition. 67(3):262-270.

Fiedor J, Burda K. 2014. Potential role of carotenoids as antioxidants in human health and disease. Nutrients. 6: 466-488.
Fraser P D, Bramley P M. 2004. The biosynthesis and nutritional uses of carotenoids. Progress in Lipid Research. 43(3):228-265.

Garrote R L, Silva E R, Bertone R A, Roa, R D. 2004. Predicting the end point of a blanching process. LebensmittelWissenschaft \& Technologie-Food Science and Technology. 37(3):309-315.

Gayen D, Ali N, Sarkar S N, Datta S K, Datta K. 2015. Down-regulation of lipoxygenase gene reduces degradation of carotenoids of golden rice during storage. Planta. 242(1): 353-363.

Gouveia, L. Empis J. 2003. Relative stabilities of microalgal carotenoids in microalgal extracts, biomass and fish feed: effect of storage conditions. Innovative Food Science \& Emerging Technologies. 4 (2):227-233.

Heo SJ, Ko SC, Kang SM, Kang HS, Kim JP, Kim SH, Lee KW, Cho MG, Jeon YJ. 2008. Cytoprotective effect of fucoxanthin isolated from brown algae Sargassum siliquastrum against $\mathrm{H}_{2} \mathrm{O}_{2}$-induced cell damage. European Food Research Technology. 228:145-151.

Heo S, Yoon W, Kim K, Oh C, Choi Y, Yoon K, Kang D, Qian Z, Choi I, Jung W. 2012. Anti-inflammatory effect of fucoxanthin derivatives Isolated from Sargassum siliquastrumin lipopolysaccharidestimulated RAW 264.7 Macrophage. Food and Chemical Toxicology. 50(9):33363342.

Heriyanto, Limantara L. 2010. Studi kandungan fukosantin dari lima jenis rumput laut coklat di perairan madura. Di dalam: Prosiding Seminar Nasional Tahunan VII pada Hasil Penelitian Perikanan dan Kelautan. Universitas Gadjah Mada, Yogyakarta. 24 Juli. Hlm1-8.

Hidayat T, Nurjanah, Anwar E, Nurilmala M. 2018. Identifikasi dan karakterisasi rumput aut tropika (dari Kepulauan Seribu) sebagai bahan baku kosmetik. Creative Research Journal. 4(2):49-62

Hii S, Choong P, Woo K, Wong C. 2010. Stability studies of fucoxanthin from Sargassum binderi. Australian Journal of 
Basic and Applied Sciences. 4(10):45804584.

Hosokawa M, Okada T, Mikami N, Konishi I, Miyashita K. 2009. Biofunctions of marine carotenoids. Food Science and Biotechnology. 18(1):1-11.

Hunterlab Association Laboratory. 2008. Hunter L, $a, b$ Color Scale. HunterLab, 8(9):1-4.

Jaswir I, Tope AHT, Raus RA, Monsur HA, Ramli N. 2014. Study on anti-bacterial potentials of some Malaysian brown seaweeds. Food Hydrocolloids. 42 (2):275279.

Kartikaningsih H, Zaelanie K. 2014. Stabilitas fukosantin dari rumput laut coklat Padina australis terhadap perubahan suhu. National Conference Green Technology. 3:366-370.

Kawee-ai A, Kuntiyab A, Kima S M. 2013. Anticholinesterase and antioxidant activities of fucoxanthin purified from the microalga Phaeodactylum tricornutum. Natural Product Communications. 8(10):1381-1386.

Kirke DA, Smyth TJ, Rai DK, Kenny O, Stengel, DB. 2017. The chemical and antioxidant stability of isolated low molecular weight phlorotannins. Food Chemistry. 221:11041112.

Kuda T, Tsunekawa M, Hishi T, Araki Y. 2005. Antioxidant properties of dried kayamonori, a brown alga Scytosiphon lomentaria (Scytosiphonales, Phaeophyceae). Food Chemistry. 89(4):617-622.

LichtenthalerH,Buschmann.2001.Chlorophylls and carotenoids: measurement and characterization by UV-VIS spectroscopy. Current Protocols in Food Analytical Chemistry. 1(1):F.4.31-4.38.

Liu LH, Zabaras D, Bennett LE, Aguas P, Woonton BW. 2009. Effects of UV-C, red light and sun light on the carotenoid content and physical qualities of tomatoes during post-harvest storage. Food Chemistry. 115 (2): 495-500.

Liu S, Zhu L, Zhang S. 2011. Study on drying technology of Sargassum fussiforme. Advanced Materials Research. 361363:764-769.
Luthfiyana N, Nurjanah, Nurilmala M, Anwar E, Hidayat T. 2016. Rasio bubur rumput laut Euchema cottonii dan Sargassum sp. sebagai formula krim tabir surya. Jurnal Pengolahan Hasil Perikanan Indonesia. 19(3): 183-195

Maeda H, Tsukui T, Sashima T, Hosokawa M, Miyashita K. 2008. Seaweed carotenoid, fucoxanthin, as a multi-functional nutrient. Asia Pacific Journal of Clinical Nutrition. 17(S1):196-199.

Magnusson M, Yuen AK, Zhang R, Wright JT, Taylor RB, MaschmeyerT, deNys RA.2017. Comparative assessment of microwave assisted (MAE) and conventional solidliquid (SLE) techniques for the extraction of phloroglucinol from brown seaweed. Algal Research. 23:28-36.

Maharany F, Nurjanah, Suwandi R, Anwar E, Hidayat T. 2017. Kandungan senyawa bioaktif rumput laut Padina australis dan Euchema cottonii sebagai bahan baku krim tabir surya. Jurnal Pengolahan Hasil Pengolahan Indonesia. 20(1): 10-17.

Mayer ME, Spiess WEL. 2003. Influence of cold storage and blanching on the carotenoid content of Kintoki Carrots. Journal of Food Engineering. 56(2-3):211-213.

Mekini'c IG, Skroza D, Šimat V, Hamed I, Cagalj M, Perkovi'c ZP. 2019. Phenolic content of brown algae (Pheophyceae) species: extraction, identification, and quantification. Biomolecules. 9(6):244

Milledge JJ, Nielsen BV, Bailey D. 2016. High-value products from macroalgae: the potential uses of the invasive brown seaweed, Sargassum muticum. Review Environment Science Biotechnology. 15: 67-88.

Nomura M, Kamogawa H, Susanto E, Kawagoe C, Yasui H, Saga N, Hosokawa M, Miyashita K. 2013. Seasonal variations of total lipids, fatty acid composition, and fucoxanthin contents of Sargassum horneri (Turner) and Cystoseira hakodatensis (Yendo) from the northern seashore of Japan. Journal of Applied Phycology. 25:1159-1169.

Nurjanah, Jacoeb MJ, Hidayat T, Chrystiawan R. 2018c. Perubahan komponen serat 
rumput laut Caulerpa sp. (dari Tual, Maluku) akibat proses perebusan. Jurnal Ilmu dan Teknologi Kelautan. 10(1): 3548.

Nurjanah, Nurilmala M, Anwar E, Luthfiyana $\mathrm{N}$, Hidayat T. 2017. Identification of bioactive compounds of seaweed Sargassum sp. and Eucheuma cottonii doty as a raw sunscreen cream. Proceedings of the Pakistan Academy of Sciences: B. Life and Environmental Sciences. 54(4): 311318.

Nurjanah, Nurilmala N, Sudiarjo F, Hidayat T. 2016. Characteristics of seaweed as raw materials for cosmetics. Aquatic Procedia. $7: 177-180$

O'Sullivan AM, O'Callaghan YC, O'Grady MN, Queguineur B, Hanniffy D, Troy DJ, Kerry JP, O'Brien NM. 2011. In vitro and cellular antioxidant activities of seaweed extracts prepared from five brown seaweeds harvested in spring from the west coast of Ireland. Food Chemistry. 126 (3):1064-1070.

Park, PK, Kim EY, Chu KH. 2007. Chemical disruption of yeast cells for the isolation of carotenoid pigments. Separation and Purification Technology. 53 (2): 148-152.

Priecina L, Karklina D, Kince T. 2018. The impact of steam-blanching and dehydration on phenolic, organic acid composition, and total carotenoids in celery roots. Innovative Food Science \& Emerging Technologies. 49:192-201

Puspita M, Déniel M, Widowati I, Radjasa O K, Douzenel P, Marty C, Vandanjon L, Bedoux G, Bourgougnon N. 2017. Total phenolic content and biological activities of enzymatic extracts from Sargassum muticum (Yendo) Fensholt. Journal of Applied Phycology. 29:2521-2537.

Rahmawaty A, Ma'ruf WF, Rianingsih L. 2014. Pengaruh penambahan oksidator dan reduktor terhadap degradasi ekstrak kasar pigmen fukosantin rumput laut Sargassum duplicatum. Jurnal Pengolahan dan Bioteknologi Hasil Perikanan. 3(4):7781.

Rattaya S, Benjakul S, Prodpran T. 2015. Extraction, antioxidative, and antimicrobial activities of brown seaweed extracts, Turbinaria ornata and Sargassum polycystum, grown in Thailand. International Aquatic Resesarch. 7:1-16.

Susanto E, Fahmi AS, Agustini TW, Rosyadi S, Wardani AD. 2017 Effects of different heat processing on fucoxanthin, antioxidant activity and colour of indonesian brown seaweeds. IOP Conference Series Earth Environmental Science. 55012063

Susanto E, Fahmi AS, Abe M, Hosokawa M, Miyashita K. 2016. Lipids, fatty acids, and fucoxanthin content from temperate and tropical brown seaweeds. Aquatic Procedia. 7:66-75.

Susanto E, Fahmi AS, Hosokawa M, Miyashita K. 2019. Variation in lipid components from 15 species of tropical and temperate seaweeds. Marine Drugs. 17(11):E630.

Terasaki M, HiroseA, Narayan N, Baba Y, Kawagoe C, Yasui H, Saga N, Hosokawa M, Miyashita K. 2009. Evaluation of recoverable functional lipid components of several brown seaweeds (phaeophyta) from japan with special reference to fucoxanthin and fucosterol contents. Journal of Phycology. 45 (4): 974-980.

Vinson J A, Su X, Zubik L, Bose P. 2001. Phenol antioxidant quantity and quality in foods: fruits. Journal Agricultural and Food Chemistry. 49 (11):5315-5321.

Wada L. Ou B. 2002. Antioxidant activity and phenolic content of oregon caneberries. Journal Agricultural and Food Chemistry. 50(12):3495-3500.

Xiao Y, Huang W, Li D, Song J, Liu C, Wei Q, Zhang M, Yang Q. 2018. Thermal degradation kinetics of all-trans and ciscarotenoids in a light-induced model system. Food Chemistry. 239:360-368.

Yilmaz B, Sahin K, Bilen H, Ibrahim H, Bahcecioglu, Bilir B, Ashraf S, Halazun K J, Kucuk O. 2015. Carotenoids and nonalcoholic fatty liver disease. Hepatobiliary Surgery Nutrition. 4(3):161-171.

Yip W H, Joe L S, Mustapha W A W, Maskat M Y, Said M. 2014. Characterisation and stability of pigments extracted from Sargassum binderi obtained from Semporna. Sabah. Sains Malaysiana. 43(9):1345-1354. 
Zaragozá MC, López D, Sáiz MP, Poquet $\mathrm{M}$, Pérez J, Puig-Parellada P, Mármol F, Simonetti P, Gardana C, Lerat Y, Burtin P, Inisan C, Rousseau I, Besnard M, Mitjavila MT. 2008. Toxicity and antioxidant activity in vitro and in vivo of two Fucus vesiculosus extracts. Journal of Agricultural and Food Chemistry. 56(17): 7773-7780.

Zhang H, Tang Y, Zhang Y, Zhang S, Qu J, Wang X, Kong R, Han C, Liu Z. 2015.
Fucoxanthin: a promising medicinal and nutritional ingredient. Evidence-Based Complementary and Alternative Medicine. 2015:1-10.

Zhao D, Daeung Y, Kim MJ, Gu MY, Kim S M, Pan CH, Kim GH, Chung DH. 2019. Effects of temperature, light, and $\mathrm{pH}$ on the stability of fucoxanthin in an oil-inwater emulsion. Food Chemistry. 291:8793. 